\title{
Influence of Season, Variety and Phosphorus Fertilization on Herbage Yield of Groundnut (Arachis hypogaea L.) in Bauchi State Nigeria
}

\author{
Y.M. Shuaibu ${ }^{a^{*}}$, S. Kawure ${ }^{\mathrm{b}}$, and R.A. Bala ${ }^{\mathrm{c}}$ \\ Department of Crop Production, Faculty of Agriculture and Agricultural Technology, Abubakar \\ Tafawa Balewa University Bauchi, Nigeria
}

aymshuaibu@atbu.edu.ng, bkawure05@yahoo.com, cummuaishat@gmail.com

Keywords: Herbage, Stover, Groundnut, Phosphorous, Yield

\begin{abstract}
An experiment was conducted at teaching and research farm of the Abubakar Tafawa Balewa University Bauchi, during the dry and rainy seasons of 2016 to evaluate the influence of variety and phosphorus fertilization on herbage yield of groundnut (Arachis hypogaea L.). The treatment consisted of two groundnut varieties (Samnut 24 and Samnut 25) and two levels of phosphorus fertilizer $(25 \mathrm{~kg}$ and $50 \mathrm{~kg} / \mathrm{ha}$ and a control) factorially combined to give six treatment combinations. These treatments were laid out in a randomized complete block design (RCBD) with four replications. Data was collected on number of branches, 100 pod weight, Harvest index, biomass yield and stover yield. All data collected were subjected Analysis of variance (ANOVA) and DMRT was adopted in separating the means. The result of the experiment revealed a significant $(\mathrm{P}=0.05)$ difference in both seasons on all the parameters observed. The results further revealed that, application of 25 and $50 \mathrm{kgP} /$ ha gave statistically $(\mathrm{P}=0.05)$ similarly result but all the treatments were better than the control. The variety on the other hand, Samnut 25 gave significantly $(\mathrm{P}=0.05)$ higher herbage yield than Samnut 24. Based on the result of this findings, application of $25 \mathrm{~kg} \mathrm{P} / \mathrm{ha}$ to Samnut 25 should be adopted by farmers for groundnut herbage production in the study area.
\end{abstract}

\section{Introduction}

Groundnut is one of the world's most popular crops cultivated throughout the tropical and subtropical areas where annual precipitation is between 1000-1200 mm for optimum growth of the crop. The crop is native to South America, Mexico and Central America [1]. Leading world producers of the crop are China, India, Nigeria, USA and Senegal. Nigeria ranks third among the major producers [2]. The total world output of the crop in 2008 was 34.8 million metric tonnes out of which Nigeria accounted for 3.8 million metric tonnes, about 11\% [3]. Groundnut has high economic and nutritional potential and is an important cash crop for peasant farmers in tropical countries including Nigeria. Industrially, the oil produced from the kernels is used for manufacturing of lubricants and other items ranging from shaving cream and soap to plastics. The seedcake has been used for livestock feed and fertilizer and shells have been utilized as filter for wallboard and insulators [4]. Seeds are rich in nondrying cooking oil (about 45\%) containing high oleic (40-47\%) and moderately high (13-35\%) in linoleic acids [5]. In Nigeria like other developing countries where the crop is grown, groundnut is excellent food, containing about $60 \%$ highly digestible protein, $22 \%$ carbohydrate, $4 \%$ minerals and about $8 \%$ fat [6]. The groundnut plays an extremely important agronomic role in the traditional farming systems as a nitrogen fixer in crop rotations [7]. Commercial production of groundnut in Nigeria is concentrated in the northern parts of the country particularly in areas between the Northern Guinea and Sudan Savanna zones [8]. The objective of this study was to determine the best variety and phosphorus levels for groundnut herbage production in Bauchi state of Nigeria.

\section{Materials and Methods}

The experiment was conducted at teaching and research farm of the Abubakar Tafawa Balewa University, Bauchi. Located at approximately $10^{\circ} 17 \mathrm{~N}, 9^{\circ} 4 \mathrm{E}$ and 609.3 meter above sea level, in the Northern guinea savanna agro-ecological zone of Nigeria. The materials used were phosphorus fertilizer (SSP) and two groundnut varieties (Samnut 24 and 25). The treatments consisted of two 
levels of phosphorus fertilizer ( 25 and $50 \mathrm{~kg} / \mathrm{ha}$ and a control) and two varieties of Groundnut (Samnut 24 and 25). These were factorially combined to give 6 treatments combinations and laid out in a randomized complete block design (RCBD) with four replications. A plot size of $3 \mathrm{x} 4 \mathrm{~m}$ was adopted, $50 \mathrm{~cm}$ was used as a boarder row and $1 \mathrm{~m}$ was left as a walkway between the replications. The two phosphorus levels were broadcasted and incorporated into different plots during seed bed preparations. The seeds of two groundnut varieties were treated with Apron star and one seed was sown per hole with more than $90 \%$ of the seed emerged 4-5 days after sowing. Weeds were controlled throughout the growing period by hoeing and hand pulling. Data was collected on Number of branches, Harvest index, 100 pod weight, Biomass and Stover yield. All data collected were subjected to analysis of variance (ANOVA) and significant differences among the treatment means were separated using Duncan's multiple Range Test (DMRT).

\section{Results and Discussion}

\section{Number of Branches}

The result as presented in table 1 revealed a significant $(\mathrm{P}=0.05)$ difference among the treatments throughout the study period. The result showed that application of phosphorous at the rate of 25 and $50 \mathrm{~kg} /$ ha gave statistically $(\mathrm{P}=0.05)$ similar number of branches, but significantly $(\mathrm{P}=0.05)$ better than the control in both the seasons under study. The result further indicated that the two varieties used were at far and samnut 25 proved to be significantly $(\mathrm{P}=0.05)$ better than samnut 24 in promoting number of branches in both the seasons. The significant $(\mathrm{P}=0.05)$ difference observed in this study indicated the importance of phosphorous fertilization in promoting number of branches of groundnut. The variation observed between the varieties could be as a result of variation in terms of genetic makeup and their response to environmental factors. The result of this experiment is in agreement with the result of [9] who reported that phosphorus deficiency is known to reduce flower production, size of pods and adversely affect the formations of root nodules which translate to the reduction in number of branches. This result is in conformity with the result of [10] who observed that application of $40 \mathrm{~kg} \mathrm{P}_{2} \mathrm{O}_{5} /$ ha had a significant effect on the number of branches/plant.

Table 1. Effect of variety and phosphorus fertilization on number branches of dry and rainy season groundnut

\begin{tabular}{|c|c|c|c|c|c|c|}
\hline \multirow[b]{3}{*}{ Treatments } & \multicolumn{5}{|c|}{ Weeks after planting } & \\
\hline & \multicolumn{3}{|c|}{ Dry Season } & \multicolumn{3}{|c|}{ Rainy Season } \\
\hline & 2 & 6 & 10 & 2 & 6 & 10 \\
\hline \multicolumn{7}{|c|}{ Phosphorus (kg/ha) } \\
\hline 0 & $7.61^{\mathrm{b}}$ & $31.77^{\mathrm{b}}$ & $91.07^{\mathrm{b}}$ & $4.08^{\mathrm{b}}$ & $16.92^{b}$ & $42.13^{b}$ \\
\hline 25 & $9.20^{\mathrm{a}}$ & $42.93^{\mathrm{a}}$ & $105.10^{\mathrm{a}}$ & $5.10^{\mathrm{a}}$ & $23.83^{\mathrm{a}}$ & $63.63^{\mathrm{a}}$ \\
\hline 50 & $9.40^{\mathrm{a}}$ & $40.83^{\mathrm{a}}$ & $101.03^{a}$ & $4.93^{\mathrm{a}}$ & $22.07^{\mathrm{a}}$ & $69.47^{\mathrm{a}}$ \\
\hline LS & $*$ & $* *$ & $*$ & $* *$ & $* *$ & $* *$ \\
\hline $\begin{array}{l}\mathrm{SE} \pm \\
\text { Variety }\end{array}$ & 0.50 & 3.13 & 3.09 & 0.18 & 1.02 & 6.30 \\
\hline Samnut 24 & $13.10^{\mathrm{b}}$ & $60.42^{b}$ & $159.83^{b}$ & 4.78 & $20.80^{\mathrm{b}}$ & $56.71^{\mathrm{b}}$ \\
\hline Samnut 25 & $14.25^{\mathrm{a}}$ & $65.01^{\mathrm{a}}$ & $170.78^{\mathrm{a}}$ & 4.63 & $24.08^{\mathrm{a}}$ & $63.44^{\mathrm{a}}$ \\
\hline LS & $*$ & $*$ & $*$ & NS & $* *$ & $*$ \\
\hline $\begin{array}{l}\mathrm{SE} \pm \\
\text { Interaction }\end{array}$ & 0.30 & 1.49 & 3.50 & 0.15 & 0.83 & 2.15 \\
\hline $\mathrm{VxP}$ & NS & NS & NS & NS & NS & NS \\
\hline
\end{tabular}

$\mathrm{LS}=$ level of significant, $\mathrm{SE}=$ Standard Error, $\mathrm{NS}=$ not significant, $* * \& *=$ significant at 0.01 and 0.05 probability level respectively, Means followed by same letter within a column are statistically same by DMRT. 


\section{Pod weight (g)}

The result in Table 2 revealed that there is a significant $(\mathrm{P}=0.05)$ difference on pod weight among the treatments throughout the study period. The study further indicated that application of phosphorous at the rate of 25 and $50 \mathrm{~kg} /$ ha gave statistically $(\mathrm{P}=0.05)$ similar pod weight, however significantly $(\mathrm{P}=0.05)$ better than the control in both the seasons under study. The study on variety however indicated that, samnut 25 was found to be significantly $(\mathrm{P}=0.05)$ better than samnut 24 in promoting heavier pods of groundnut in both the seasons for the study. The significant $(\mathrm{P}=0.05)$ difference observed in this study on pod weight showed the role of phosphorous fertilization in terms of groundnut pod formation and grain filling. The result of this experiment lend its support from the report of [11] who reported that increasing phosphorus levels increased shoot dry weight, number of pods and seed of groundnut.

\section{Harvest index (\%)}

Table 2 presented the result on harvest index of groundnut, the result indicated that, there is a significant $(\mathrm{P}=0.05)$ difference among the treatments used throughout the study period. The study further showed that application of phosphorous at the rate of 25 and $50 \mathrm{~kg} /$ ha gave statistically $(\mathrm{P}=0.05)$ same harvest index but significantly $(\mathrm{P}=0.05)$ better than the control in both the seasons under study. The study on variety, however, indicated that the two varieties were statistically $(\mathrm{P}=0.05)$ similar with regards to harvest index. in both the seasons for the study. The significant $(\mathrm{P}=0.05)$ difference observed in this study revealed the role of phosphorous fertilizer in promoting photosynthesis and metabolism of carbohydrates for subsequent used in growth and reproduction. The result of this experiment is in conformity with the result of [12] who reported that, application of phosphorus stimulate pod setting, pods weight, decreases number of unfilled pods and influence the harvest index of groundnut. The result of the present findings also lend support to that of [13] who reported that application of $60 \mathrm{~kg} \mathrm{P}_{2} \mathrm{O}_{5}$ significantly $(\mathrm{P}=0.05)$ increased number of pods per plant, shelling percentage, pod, haulm and harvest index of groundnut.

Table 2. Effect of variety and phosphorus fertilization on 100 pod weight and harvest index of dry and rain season groundnut

\begin{tabular}{|c|c|c|c|c|}
\hline \multirow[b]{3}{*}{ Treatments } & \multicolumn{2}{|r|}{ Parameters } & \multirow{2}{*}{\multicolumn{2}{|c|}{ Rainy Season }} \\
\hline & \multicolumn{2}{|c|}{ Dry Season } & & \\
\hline & 100 Pod Weight & Harvest Index & 100 Pod Weight & Harvest Index \\
\hline \multicolumn{5}{|c|}{ Phosphorus (kg/ha) } \\
\hline 0 & $97.73^{b}$ & $0.30^{\mathrm{b}}$ & $68.48^{\mathrm{b}}$ & $0.11^{\mathrm{b}}$ \\
\hline 25 & $152.73^{\mathrm{a}}$ & $0.35^{\mathrm{a}}$ & $77.16^{\mathrm{a}}$ & $0.16^{\mathrm{a}}$ \\
\hline 50 & $160.53^{\mathrm{a}}$ & $0.34^{\mathrm{a}}$ & $79.82 \mathrm{a}$ & $0.17^{\mathrm{a}}$ \\
\hline LS & $* *$ & $* *$ & $* *$ & $* *$ \\
\hline $\mathrm{SE} \pm$ & 14.25 & 0.03 & 1.28 & 0.01 \\
\hline $\begin{array}{l}\text { Variety } \\
\text { Samnut } 24\end{array}$ & $196.46^{\mathrm{b}}$ & 044 & $6982^{b}$ & 16 \\
\hline Samnut 25 & $23330^{\mathrm{a}}$ & $\begin{array}{l}0.44 \\
0.40\end{array}$ & $8048^{a}$ & 0.16 \\
\hline & & 0.49 & & 0.14 \\
\hline LS & * & NS & $* *$ & NS \\
\hline $\begin{array}{l}\mathrm{SE} \pm \\
\text { Interaction }\end{array}$ & 10.38 & 0.08 & 1.90 & 0.01 \\
\hline $\mathrm{VxP}$ & NS & NS & NS & NS \\
\hline
\end{tabular}

$\mathrm{LS}=$ level of significant, $\mathrm{SE}=$ Standard Error, $\mathrm{NS}=$ not significant, ${ }^{*} \& * *=$ significant at 0.01 and 0.05 probability level respectively, Means followed by same letter within a column are statistically same by DMRT. 


\section{Biomass yield (g)}

The result in Table 3 revealed that, there is a significant $(\mathrm{P}=0.05)$ difference on biomass yield among the treatments throughout the study period. The study further indicated that application of phosphorous at the rate of 25 and $50 \mathrm{~kg} /$ ha gave statistically $(\mathrm{P}=0.05)$ similar biomass yield, however significantly $(\mathrm{P}=0.05)$ better than the control in both the seasons under study. The study on variety, however, indicated that, samnut 25 was found to be significantly $(\mathrm{P}=0.05)$ better than samnut 24 in promoting biomass yield of groundnut in both the seasons for the study. The significant $(\mathrm{P}=0.05)$ difference observed in this study proved the importance of fertilizer application in groundnut production. This result is in line with the findings of [14] who reported that $\mathrm{P}_{2} \mathrm{O}_{5}$ application significantly increased herbage yield of groundnut. The result of this experiment is also in agreement with the result of [15] who reported that the optimum production of groundnut requires balanced nutrition as nutrient deficiencies can have adverse effect on stover and yield components of groundnut.

\section{Stover yield (g)}

The result as presented in Table 3 revealed that there is a significant $(\mathrm{P}=0.05)$ difference among the treatments on stover yield throughout the study period. The study further indicated that application of phosphorous at the rate of 25 and $50 \mathrm{~kg} /$ ha proved to give statistically $(\mathrm{P}=0.05)$ similar result on stover yield, however significantly $(\mathrm{P}=0.05)$ better than the control in both the seasons under study. Variety on the other hand, samnut 25 gave significantly $(\mathrm{P}=0.05)$ higher stover yield than samnut 24 in both the seasons for the study. The significant $(\mathrm{P}=0.05)$ difference observed in this study indicated the effect of phosphorus in hastening the maturation of groundnut and improving the quality of haulm of the crop. The result is in conformity with the result of [11] who revealed that increasing of $\mathrm{P}_{2} \mathrm{O}_{5}$ levels increased pod dry weight, number of pods and stover yield of groundnut. This result also lends its support to the findings of [16] who reported that variety and phosphorous fertilization play a significant role in promoting stover yield of groundnut.

Table 3. Effect of variety and phosphorus fertilization on biomass and stover yield of dry season and rainfed groundnut

\begin{tabular}{|c|c|c|c|c|}
\hline \multirow[b]{3}{*}{ Treatments } & \multicolumn{2}{|r|}{ Parameters } & \multirow{2}{*}{\multicolumn{2}{|c|}{ Rainy Season }} \\
\hline & \multicolumn{2}{|c|}{ Dry Season } & & \\
\hline & Biomass Yield & Stover Yield & Biomass Yield & Stover Yield \\
\hline \multicolumn{5}{|c|}{ Phosphorus (kg/ha) } \\
\hline 0 & $2.62^{b}$ & $2.54^{\mathrm{b}}$ & $2.10^{\mathrm{b}}$ & $2.75^{\mathrm{b}}$ \\
\hline 25 & $4.68^{\mathrm{a}}$ & $3.64^{\mathrm{a}}$ & $4.09^{\mathrm{a}}$ & $3.28^{\mathrm{a}}$ \\
\hline 50 & $4.69^{\mathrm{a}}$ & $3.65^{\mathrm{a}}$ & $4.80^{\mathrm{a}}$ & $3.19^{\mathrm{a}}$ \\
\hline LS & $* *$ & $* *$ & $* *$ & $* *$ \\
\hline $\mathrm{SE} \pm$ & 0.01 & 0.03 & 0.45 & 0.19 \\
\hline Variety & & & & \\
\hline Samnut 24 & $2.71^{\mathrm{b}}$ & $2.71^{\mathrm{b}}$ & $3.53^{\mathrm{b}}$ & $2.75^{\mathrm{b}}$ \\
\hline Samnut 25 & $3.81^{\mathrm{a}}$ & $3.84^{\mathrm{a}}$ & $4.16^{\mathrm{a}}$ & $3.85^{\mathrm{a}}$ \\
\hline LS & $*$ & $*$ & $*$ & $* *$ \\
\hline $\mathrm{SE} \pm$ & 0.01 & 0.02 & 0.17 & 0.16 \\
\hline Interaction & & & & \\
\hline $\mathrm{VxP}$ & NS & NS & NS & NS \\
\hline
\end{tabular}

$\mathrm{LS}=$ level of significant, $\mathrm{SE}=$ Standard Error, $\mathrm{NS}=$ not significant, ${ }^{*} \& * *=$ significant at 0.01 and 0.05 probability level respectively, Means followed by same letter within a column are statistically same by DMRT. 


\section{Conclusion and Recommendation}

In conclusion, however, application of phosphorous fertilizer significantly influenced the herbage yield of groundnut. Similarly, it can be concluded that Samnut 25 performed better in terms of herbage yield of than Samnut 24. Based on the result of this experiment, the application of phosphorous fertilizer at the rate of $25 \mathrm{~kg} /$ ha to Samnut 25 variety should be adopted by farmers in the study area for good groundnut herbage production.

\section{Conflict of Interest}

The authors declared that there is no conflict of interest.

\section{References}

[1] J. Y. Yayock, Effects of population density and leaf spot control on yields of groundnut (Arachis hypogaea L.) in Nigeria, Samaru Journal of Agricultural research. 4 (1981) 200-205.

[2] A.B. Garba, M. Auwalu, S.D. Abdul, Effect of variety and intra-row spacing of flonar production in groundnut under the rrevailing weather condition of the Northern Guinea, Nigerian Journal of Agricultural Technology. 9(2) (2002) 102-113.

[3] H.S.B. Rao et al., Experimental investigation on engine performance of diesel operation on peanut seed oil biodiesel blends, International Journal of Current Engineering and Technology. 3 (2013) 1429-1435.

[4] D.K. Okello, M. Biruma, C.M. Deom, Over view of groundnut research in Uganda, Past, Present and Future African Journal of Biotechnology. 9 (2010) 6448-6459.

[5] K. Razaul et al., Effect of Phosphorus, calcium and Boron on the growth and yield of Groundnut (Arachis hypogea), International journal of Bio-science and bio-Technology. 5 (2013) 3-7.

[6] S. Singh, Phenotypic diversity and identification of wild Arachis accessions with useful agronomic and nutritional traits, Euphytica. 82 (2004) 103-115.

[7] V.B. Taru, I.Z. Kyagya, S.I. Mshelia, Profitability of Groundnut Production in Michika Local Government Area of Adamawa State, Nigerian Journal of Agricultural Science. 1(1) (2010) 25 29.

[8] NAERLS. Recommended practices for groundnut production. National Agricultural extension Liason Service, Extension recommended practice. 1 (2010) 5-6.

[9] A. Singh et al., Influence of planting techniques and plant population on Biology and pod productivity of summer groundnut varieties, Crops Research. 6(1) (2005) 173-174.

[10] R.A.S. Tomar, H.S. Kushwaha, S.P.S. Tomar, Response of groundnut (Arachis hypogaea L.) varieties to pphosphorus and zinc under rain fed conditions, Indian Journal of Agronomy. 35 (1990) 391-394.

[11] S.F. El-Habbasha et al., Effect of Phosphorus levels andsome Biofertilizers on dry matter, yield and yield attributes of groundnut, Bull. Fac. Agric. Cairo Univ. 56 (2005) 237-252.

[12] A.Y. Kamara et al., Phosphorus effects on the growth and yield of groundnut varieties in the tropical savannas of north-east Nigeria, Journal of Tropical Agriculture. 49(2) (2011) 25-30.

[13] R.D. Kwari, Soil fertility Status in some communities of sourthern Borno. PROSAB, Nigeria. (2005) 21-25.

[14] I.A. El-Far, B.R. Ramadan, Response of yield, yield components and seed quality of groundnut (Arachis hypogaea L.) to plant density and PK fertilization in sandy calcareous soil, in: Proceedings of the 9th Agronomy Conference, Minufiya University, Egypt. Sept. 2000 , pp. 453-466.

[15] S. Panda, J.N. Rao, Effect of plant population densities on the severity of late leaf spot and rust of groundnut plant pathology, International Crop Research Institute for the Semi-Arid Tropics. 18 (2002) 271-278.

[16] A.S. Abdallah, Growth and yield response of groundnut (Arachis hypogaea L.) to microbial and phosphorus fertilizers, Journal of Agriculture, Food and Applied Science. 1 (2013) 78-85. 